\title{
Legal Protection of International Labour Organization (ILO) and Indonesia toward Indonesia Illegal Migrant Workers
}

\author{
Theddy ${ }^{1}$, Ningrum Natasya Sirait ${ }^{2}$, Agusmidah $^{3}$, Rosmalinda $^{4}$ \\ 1,2, 3,4 Universitas Sumatera Utara \\ Email: theddy_thahir@gotmail.com
}

\begin{abstract}
There are a lot of Indonesia Migrant Workers (IMW) work at overseas with illegal status, illegal means unprocedural and/or undocumented. They faced a lot of problems and do not have any rights given. Tough to the status, states should be full responsible to protect IMW This research is using doctrinal method. This research is using statutes, cases, comparative, and conceptual approaches. Data collected in this research are from primary and secondary legal material with library research and other documents International law protects IMW with international treaties, while Indonesia is using the domestic law to protect every IMW. ILO protects IMW by providing conventions, observations, cooperation with every states and social dialogue. Indonesia protects IMW with national law as the placement of IMW by Badan Penempatan Pekerja Migran Indonesia (BP2MI) and legal enforcement to anyone who place IMW illegally. International law is great to protect IMW even with illegal status. International law affects national law to protect IMW. As there are state responsibility theory, Indonesia takes any actions to protect IMW along with the illegal status
\end{abstract}

Keywords: illegal, ILO, IMW, legal protection

\section{INTRODUCTION}

Every nations all around the world are working on Decent Work, which is one of the 17 goals of Sustainable Development Goals (SDGs) in order to protect every migrant workers all around the world. [1] The purpose of migration is to have welfare for every migrant workers. There are many unavailable job markets in some countries, so a lot of migrant workers have to migrate to other countries. [2]

An ILO report shows that every migrant workers are working as domestic workers with estimation 11.5 million people under 15 years old with $80 \%$ girls. [3] Indonesia has limitations for everyone to have a good job and decent wages. Those situations force a lot of Indonesian have to go abroad to find a suitable job, in order to get earnings and fulfill their families' needs. Mostly, Indonesia Migrant Workers (IMW) work as domestic workers overseas, such as Malaysia, Hong Kong, Taiwan, and others. [4]

There are no any accurate data for IMW all around the world. World Bank shows that there are around 9 million Indonesian workers who work in 150 countries. [5] Data based on Badan Pelindungan Pekerja Indonesia (BP2MI) are around 5,3 million who worked as illegal migrant workers, who were sent by illegal agencies. [6]

\begin{tabular}{|l|l|l|l|l|l|l|}
\hline \multicolumn{6}{|l|}{ Table 1. Placement Statistic of Indonesia Migrant Workers based on Formal and Informal Sector 2011-2020 } \\
\hline No. & Year & Total & Formal & $\%$ & Informal & $\%$ \\
\hline 1 & 2011 & 586.802 & 266.191 & 45 & 320.611 & 55 \\
\hline 2 & 2012 & 494.609 & 258.411 & 52 & 236.198 & 48 \\
\hline 3 & 2013 & 512.168 & 285.297 & 56 & 226.871 & 44 \\
\hline 4 & 2014 & 429.872 & 247.610 & 58 & 182.262 & 42 \\
\hline 5 & 2015 & 275.737 & 152.395 & 55 & 123.342 & 42 \\
\hline 6 & 2016 & 234.451 & 125.176 & 53 & 109.275 & 47 \\
\hline 7 & 2017 & 261.820 & 118.830 & 45 & 142.990 & 55 \\
\hline 8 & 2018 & 264.092 & 133.640 & 51 & 130.452 & 49 \\
\hline
\end{tabular}




\begin{tabular}{|l|l|l|l|l|l|l|}
\hline 9 & 2019 & 276.553 & 133.993 & 48 & 142.560 & 52 \\
\hline 10 & 2020 & 113.173 & 36.784 & 32 & 76.389 & 68 \\
\hline
\end{tabular}

\begin{tabular}{|l|l|l|l|l|}
\hline \multicolumn{5}{|l|}{ Table 2. Incoming Statistic of Indonesia Migrant Workers based on Countries from 2008 to 2020} \\
\hline No. & Countries & 2018 & 2019 & 2020 \\
\hline 1 & Malaysia & 34.192 & 39.493 & 15.075 \\
\hline 2 & Hong Kong & 10.258 & 16.397 & 12.042 \\
\hline 3 & Taiwan & 15.043 & 20.952 & 10.164 \\
\hline 4 & Singapore & 12.599 & 12.068 & 4.697 \\
\hline 5 & Saudi Arabia & 7.783 & 4.429 & 1.351 \\
\hline 6 & Italy & 1.065 & 918 & 1.227 \\
\hline 7 & Brunei Darussalam & 5.315 & 3.480 & 1.196 \\
\hline 8 & South Korea & 3.528 & 2.272 & 1.133 \\
\hline 9 & United Emirate Arab (UEA) & 3.895 & 1.042 & 276 \\
\hline 10 & Others & 15.882 & 6.503 & 2.050 \\
\hline Total & & 109.560 & 107.554 & 49.211 \\
\hline
\end{tabular}

Source : BP2MI, published in 2020

From table 1 and 2, we could concluded that a lot of IMW are working overseas. Mostly, they worked in informal sector. This tables on collected by BP2MI, but it is far from the data from ILO which discovered more to illegal than legal migrant workers.

There are a lot of Indonesia Illegal Migrant Workers (IIMW) in all around the world. Generally, they all were exploited as shipmen, domestic workers, and other professions. [7] All these professions faced a lot of problems because they were illegal, undocumented, and not registered in Indonesia's representative in the country they worked. [8] There are also irregular form of illegal migrant workers who have documents but unprocedural, when they go with tourism visa but work as a workers which should be supported with working visa. For example in Taiwan, IIMW worked as domestic workers. [9] All forms of illegal

Any countries should not employ any illegal migrant workers. Article 6 section (1) of ILO C143 - Migrant Workers stating that provision shall be made under national laws or regulations for the effective detection of the illegal employment of migrant workers and for the definition and the application of administrative, civil and penal sanctions, which include imprisonment in their range, in respect of the illegal employment of migrant workers, in respect of the organization of movements of migrants. [32] In this convention, any kind of illegal forms should be abolished. Every states under their national law must regulate any regulations that abolish any forms of illegal migrant workers. migrant workers had to face a lot of legal problems and could not have their rights. [10]

IMW should be departed by government, private legal corporation, or themselves. In private sector, there are a lot of private agencies such as corporate and personal illegal agencies to depart IMW working overseas. BP2MI has discovered there are a lot of illegal departure agencies that departing IMW to work overseas.[11] Example in Bogor, Jawa Barat there was around 19 IMW that will be working in Thailand in 17 July 2020 who recruited by PT Duta Buana Bahari and PT Nadies Citra Mandiri. [11] They are not legal corporate that may recruit IMW. This is just one example, that shows IMW could be illegal because starting from the recruiting process has already illegal.

All illegal agencies still operating because the law enforcement is not good enough. Law enforcement should be the tool to prevent and handle any illegal agencies in Indonesia.

IIMW mainly work as domestic workers, seamen, and other low-skilled with low wages. IIMW do not have bargaining position and their working rights such as standard wages, leave, social security, insurance, and others. [12]

With all those introduction, this paper come to one research question, what are ILO's legal protections and Indonesia's National Law legal protects in order to protect Indonesia Illegal Migrant Workers ?

This research is using statutes approach, cases approach and conceptual approach with normative method. This research is analyzing international law primary source of law about migrant workers and 
national law concerning about IMW. Data gathered from national regulations, court decisions (court ruling), previous research and other legal document.

\section{LEGAL PROTECTION OF INTERNATIONAL LABOUR ORGANIZATION}

ILO is a special body of UN in labour aspects. There are four main purposes of ILO, such as provide treaties, observation and reporting, cooperating with every countries, and social dialogue. Every states as the ILO members should signed and ratified ILO conventions. Even ILO conventions are not binding and forcing, ILO is the main body to provide a labour standard to any migrant workers. [13]

There are two treaties that provided by ILO concerning migrant workers. One, ILO C97 Migration for Employment Convention (Revised), 1949, that rules about any migration activities by migrant workers who work in other countries. [33] Second, ILO C143 - Migrant Workers, 1975, that rules about the facilities to migrant workers, there should be working agreements between states, abolishing human trafficking, and provide social protection equally to every migrant workers. [32]

This two conventions of ILO, lead to a new convention under UN, that is International Convention on the Protection of the Rights of All Migrant Workers and Members of Their Families (ICRMW). This convention adopted from General Assembly Resolution 45/158 of 18 December 1990. This convention only ratified by 56 countries until 2021 , with 39 countries have signed and 103 countries have not participated.

ICRMW provide norms in international and national regulations in the enforcement and legal protections. This convention prioritizes states relations in exchange information, decreasing illegal migrant workers, smuggling migrant workers, human trafficking and other rights. [14]

Any problems in every countries, such as human trafficking, violence, slavery, forcing, or other bad treatments should be abolished with ILO conventions. [15] ILO makes sure every migrant workers around the world have legal status, with the benefit easily has working permission, amnesty, and other treatments towards migrant workers. [16]

Illegal migrant workers issues related to human rights because it is the human fundamental essences. Issues between human rights are internationally faced by every countries and international governmental organizations. [17] Human rights are not only just a conceptual, but in practical, every conditions related to migrant workers should be better. [18] Human rights in UN Charter are binding for every states, with Jus Cogens in every international treaties, customary international law and other international obligations to protect every migrant workers even with illegal status.
ILO's first purpose is to provide treaties. ILO C97 and $\mathrm{C} 143$ are binding for every states who ratified those. Even one state has ratified those, other states cannot intervene other states, with the principle of non-intervention. [19] This also another problem faced by every states, when state only could diplomatically negotiating about their origin migrant workers, not intervene, even UN or ILO. [20] IIMW could not be protected even one state has ratified, it would be worsen if there are states which IIMW working without ratified ILO conventions.

ILO's second purpose is to monitoring and reporting about every conventions that ratified by any states. ILO always reporting the data of any migrant workers around the world. For example, ILO has a report that shows every migrant workers mainly work as domestic workers above 15 years old, which $80 \%$ are women. [21] This report shows that high-income countries accommodate around 9,1 from 11,5 millions migrant domestic workers. [21]

ILO observation with other institutes give reports about IMW problems, and any other aspect of IMW around the world. There is a report that showed IMW who worked in Malaysia as domestic workers being exploited because mostly IMW were illegal. [22] IMW came from sea or land, mostly are undocumented. As IMW were illegal, they were being exploited caused by fake documents and visa. This caused they became sex workers, human trafficking, violence, and nothing they could have done to face all the troubles in Malaysia. [22]

ILO's third purpose is to cooperating between states to prevent IIMW. This third purpose is to cooperating not only between states, but also international organizations. One example, ILO - UN Women Safe and Fair Program, whereas European Union (EU), United Nation and Association of Southeast Asian Nations (ASEAN) to support migrant workers in Thailand. [23] This program is to show that any migrant workers who work in Southeast Asia and Asia-Pasific around 9,1 millions migrant workers. [23]

ILO give suggestions to regional agreements or bilateral agreements in labour aspect in order to achieve the same results.[24] Example, there are a Memorandum of Understanding (MoU) between Indonesia and Malaysia in labour aspects, MoU between Thailand and Myanmar, MoU Thailand and Laos in the exploitation of women and children, and other MoU that often held between states to protect migrant workers. [24]

In 2006, ILO cooperates with Indonesia in one program to enhance the legal protection of IMW. This 
program is under the Overseas Ministry in 2006. After the program, Indonesia made a new body, Badan Nasional Perlindungan Tenaga Kerja Indonesia (BP2TKI). This body is to protect IMW. [25]

In 2019, ILO cooperating with Serikat Buruh Migran Indonesia (Indonesia Migrant Workers Union) and Labour Ministry. The purposes of this program are improving the service of women migrant workers and their families in village level. [26] There are 36 villages join the program. This program supported by EU with the encouraging leadership, organization, and migrant workers networks. [26]

ILO's forth purpose is doing social dialogue. ILO is the only $\mathrm{UN}$ body that has tripartite functions to promote decent work. [27] ILO Declaration 2008 on Social Justice for a Fair Globalization, emphasizes four main Decent Work Agenda, such as:

a) Promoting employment by creating a sustainable institutional and economic environment;

b) Developing and enhancing measures of social protections - social security and labour protection which are suitable and adapted to national circumstances;

c) Promoting social dialogue and tripartism [34] as the most appropriate methods for: adapting the

\section{LEGAL PROTECTION OF INDONESIA'S NATIONAL LAW}

Placement should be held by BP2MI under the Regulation No. 18/2017 in article 50. Placement by BP2MI must be written between government with

Legal protections for IMW become the responsible for everyone and every institutions. First, Central Government and Regional Government under Article 76 Section (1) of Regulation 18/2017 become the main actors to protect, and monitor IMW. Second, society may also participate under Article 76 Section (2) of Regulation 18/2017.

Before the placement, there is a phase, recruitment phase. This is the essential phase because this also become the prevention efforts to prevent any illegal recruitment that commonly occurred. There was a case in Cianjur District, Jawa Barat which a lot of IIMW being exploited and violated. In order to prevent and protect IIMW, the Regional Government provided a regulation about placement and protection to IMW.[28] This regulation only applied in Jawa Barat, not other provinces.

Indonesia always be there to protect every IMW from recruitment, and placement with legal status and documented to work overseas. Aside from placement problems, IMW often faced administrative documents problems, that also should be solved by Indonesia's governments.

After legal recruitment and placement for IMW, other legal protection is law enforcement to any illegal agencies and corporations that are not legally have the authorities to recruit and place IMW abroad. The law enforcement under Regulation No. 18/2017 implementation of the strategic objectives to the needs and circumstances of each country; translating economic development into social progress, [35] and social progress into economic development; facilitating consensus building on relevant national and international policies that impact on employment and decent work strategies and programmes; [36] and making labour law and institutions effective, including in respect of the recognition of the employment relationship, the promotion of good industrial relations and the building of effective labour inspection systems; and

d) Respecting, promoting, and realizing the fundamental principles and rights at work, which are of particular significance, as both rights and enabling conditions that are necessary for the full realization of all of the strategic objectives.

All of function in ILO is to promote any migrant workers around the world, in this paper, specific for IIMW. Any function is to protect IIMW. If all the function in ILO occur around the world, IIMW would not occur anymore. IIMW will be placed legally and working based on countries' regulations in IMW working countries.

destination countries or government with legal corporations in other countries. This rule means that Indonesia takes full responsibility to place IMW.

is considered not good enough as a lot of violations could not be proceed to trial process. [29]

Under the Regulation No. 18/2017, there are two kind of law enforcement, administration sanction and penal sanction. Administration sanction ruled in Article 74 section (1) about warning written, temporary suspension some or whole activities or revocation license.

Corporations are only could be sanctioned with administrative enforcement. [30] This means that every corporations must take full responsibility to place and protect IMW have sent by them. Indonesia still protect those IMW sent by corporates, but corporates take full charges toward IMW they have sent.

There was a research in Tuluagung District, Jawa Timur Province, showed a lot of illegal corporates still operating in placing IMW overseas and not based on working agreement documents. Those corporates will be sanctioned with administrative and criminal sanction. [31]

After the legal placement and recruitment by BP2MI, and law enforcement,

Indonesia will not have any IIMW anymore. This the purpose of ILO's labour standard and Indonesia's Governments' commitment in order to protect IMW around the world. 


\section{CONCLUSION}

Any efforts done by ILO such as making treaties, observing and reporting, cooperating and social dialogue are to handle and protect IIMW. While Indonesia, any placement by BP2MI is bylaw, and enforcement to anyone who place IIMW should be enforce more in order to abolish any illegal placement and movement for IMW all around the world.

\section{AUTHORS' CONTRIBUTIONS}

As the contributions, researchers empower and publish this research in order to make some contributions to know IMW situations, any IIMW situations, and protections should be given to any migrant workers all around the world.

\section{ACKNOWLEDGMENT}

This research is the acknowledgement to Universitas Sumatera Utara, especially Law Faculty that always supports to finish this research.

\section{REFERENCES}

[1] Shirin M. Rai, Benjamin D. Brown, Kanchana N. Ruwanpura, SDG 8: Decent work and economic growth - A gendered analysis, World Development 113, 2019, pp 368-380

[2] Charles F. Mueller, The Economics of Labor Migration,

[3] Elisa Menegatti, "Protecting Migrant Domestic Workers: The international legal framework at a glance", Global Action Programme on Migrant Domestic Workers and Their Families, ILO, 2013

[4] Asian Migrant Center, Country Migration Profile (Destination country): Hong Kong, https://docs.wixstatic.com/ugd/c2180c b45fdb5 32a0f434b85e348 a03b856a78.pdf

[5] https://nasional.sindonews.com/read/96108/15/ bp2mi-53-juta-pekerja-migran-ilegal-takmasuk-perlindungan-negara-1594310825, accessed 4 September 2021

[6] Abdul Ghofar, "Data Collection Placement and Protection of Indonesia Overseas Worker," The National Board for The Placement and Protection of Indonesia Overseas Worker (BNP2TKI), Bangkok, 5-8 Februari 2019

[7] The World Bank, Indonesia's Global Workers: Juggling Opportunities \& Risks, Jakarta: The World Bank Office Jakarta, 2017

[8] https://www.antaranews.com/berita/1968668/de rita-pekerja-migran-indonesia-nonproseduraldi-negeri-orang, accessed 4 September 2021

[9] Dinda Noor Utami, "Upaya Indonesia dalam Menyelesaikan Permasalahan Pekerja Migran
Indonesia di Taiwan 2018-2020," eJournal Ilmu Hubungan Internasional, Vol. 8 No. 4, 2020, pp 848-860

[10] https://news.detik.com/berita-jawa-timur/d4488172/nestapanya-nasib-tki-tak-dibayarmeski-bertahun-tahun-kerja-di-malaysia, accessed 4 September 2021

[11] https://www.cnnindonesia.com/nasional/202007 22000103-12-527391/bp2mi-ungkap-biro-tkiilegal-berkantor-di-apartemen-bogor, accessed 4 September 2021

[12] https://news.detik.com/berita-jawa-timur/d4488172/nestapanya-nasib-tki-tak-dibayarmeski-bertahun-tahun-kerja-di-malaysia, accessed 4 September 2021

[13] https://www.ilo.org/global/standards/introductio n-to-international-labour-

standards/international-labour-standardsuse/lang--en/index.htm,

https://www.ilo.org/global/standards/applyingand-promoting-international-labour-

standards/lang--en/index.htm, accessed 4 September 2021.

[14] The International Steering Committee for the Campaign for Ratification of the Migrants Rights Convention, Guide on Ratification of the International Convention on the Protection of the Rights of All Migrant Workers and Members of Their Families (ICRMW), (Geneva, 2009)

[15] International Legal Framework for the Protection of Migrant Workers pada https://www.osce.org/files/f/documents/b/a/192 46.pdf, accessed 4 September 2021

[16] ILO, "Pelindungan pekerja migran selama pandemic COVID-19”, Risalah Kebijakan ILO, 2020

[17] Patricia Rinwigati Waagstein, “Justifying Extraterritorial Regulations of Home Country on Business and Human Rights", Indonesia Journal of International Law, Vol. 16 No. 3, 2019, hlm. 386

[18] Jennifer A. Zerk, Multinationals and Corporate Social Responsibility, (Cambridge: Cambridge University Press, 2006)

[19] R. J. Vincent, "The Principle of NonIntervention and International Order", Disertasi, Australian National University, 1971

[20] J. Gerber, "Beyond Balancing: International Law Restraints on the Reach of National Laws", The Yale Journal of International Law Vol. 10, 1984

[21] Elisa Menegatti, "Protecting Migrant Domestic Workers: The international legal framework at a glance", Global Action Programme on Migrant Domestic Workers and Their Families, ILO, 2013

[22] International Labour Office, "Conference Committee on the Application of Standards: 
Extracts from the Record of Proceedings", Geneva, 2014, Part II

[23] https://www.ilo.org/asia/mediacentre/news/WCMS_774907/lang-en/index.htm, accessed 10 Oktober 2021.

[24] https://www.ilo.org/asia/areas/labourmigration/WCMS_161105/lang--en/index.htm, accessed 10 Oktober 2021.

[25] International Labour Organization, "10 Tahun Menangani Migrasi Kerja di Indonesia Bersama Bisa "Together it's possible"", Jakarta

[26] https://www.ilo.org/jakarta/info/public/fs/WCM S_781827/lang--en/index.htm, accessed 10 Oktober 2021

[27] International Labour Organization, "Program Pekerja Layak Nasional (DWCP) untuk Indonesia 2020-2025", Jakarta, 2020

[28] Henny Nuraeny, "Trafficking of Migrant Workers in Indonesia: A Legal Enforcement and Economic Perspective of Prevention and Protection Efforts", European Research Studies Journal, Vol. XX, Issue 4B, 2017

[29] Celia Tara Avisha Magenda, Michael G. Nainggolan dan Stefan O. Voges, "Perlindungan Hukum bagi Pekerja Migran Indonesia (PMI) di Luar Negeri dalam Kaitannya dengan Tugas Perwakilan Diplomatik", Lex Administratum, Vol. IX No. 4, 2021, pp 130-139

[30] International Labour Organization, General Principles and Operational Guidelines for Fair Recruitment and Definition of Recuitment Fees and Related Costs, (Geneva: International Labour Office, 2019)

[31] Azaria Yasmine, "Penegakan Hukum terhadap Perusahaan Penempatan Pekerja Migran Indonesia Ilegal", Jusrist-Diction, Vol. 2 No. 5, 2019, pp 1593-1609

[32] https://www.ilo.org/dyn/normlex/en/f?p=NOR MLEXPUB:12100:0::NO::P12100_INSTRUM ENT_ID:312288, accessed 2 November 2021

[33] https://www.ilo.org/dyn/normlex/en/f?p=NOR MLEXPUB:12100:0::NO::p12100_instrument id:312242, accessed 2 November 2021

[34] https://www.ilo.org/wcmsp5/groups/public/--ed_norm/--relconf/documents/meetingdocument/wcms_62 4015.pdf, accessed 2 November 2021

[35] https://www.ituccsi.org/IMG/pdf/tudcn_issue_paper__social_dialogue_development_en.pdf?_cf_ch 1_jschl_tk_=pmd_GK4OA57lvB_Fn1jrqzOsg3 OPxQC6jy6uomOkVlC_RlE-1635856549-0gqNtZGzNApCjcnBszQe9, accessed 2 November 2021

[36] https://www.ilo.org/wcmsp5/groups/public/--ed_norm/--relconf/documents/meetingdocument/wcms_77 6811.pdf, accessed 2 November 2021 